\title{
Study on Urban Underground Streets in Modern Cities
}

\author{
Zhongkun Zhang \\ College of Architecture Engineering, Binzhou University, Binzhou, China
}

Email address:

blueskylakegrass@sina.com

To cite this article:

Zhongkun Zhang. Study on Urban Underground Streets in Modern Cities. American Journal of Civil Engineering.

Vol. 6, No. 2, 2018, pp. 60-67. doi: 10.11648/j.ajce.20180602.12

Received: January 19, 2018; Accepted: March 14, 2018; Published: April 27, 2018

\begin{abstract}
Through the analysis of urban underground streets development and present urban construction situation over the world, based on the underground streets in the meaning of commercial supplementary and comprehensive environmental improvement function, combined with China's national conditions, it is studied in the field of urban underground streets planning for urban underground space construction. The commercial advantage of urban underground streets is of unique performance. On the one hand, underground streets without rain and snow weather factors on shopping, as is very attractive to consumers, and undoubtedly of positive significance to the active markets and the economic prosperities; on the other hand, the underground streets provide not only leisure and pleasure for people, but also safe and convenient shopping environment for people, as are the main reasons to attract customers. The construction of underground streets improves the transportation for human activities in modern cities. We should treat the urban and the underground space as a whole and set up the urban planning system in line with the requirements of the three-dimensional construction of the city. It is high time to make full use of the valuable resource of urban underground space and to promote scientific and reasonable planning of urban underground streets for prosperities of modern cities.
\end{abstract}

Keywords: Underground Streets, Underground Space, Planning and Construction

\section{Introduction}

Urban underground streets have been developing in recent decades in the world. They are products of modern urban development and have become parts of people's living environment. The modern cities, both in developed and developing countries, energy consumption is high in different degree. Although the specific content of the environmental problems in different cities and suburban towns shows different, but some of the infrastructures are suffering beyond the carrying capacity of the loading, and the continuous expansion of the functions of cities. Urban space is in a serious shortage with the increasing needs of people living in cities. The construction of underground streets is one of the very effective measures to solve the above problems. In the twenty-first Century, the construction of Chinese underground streets has been undoubtedly played a decisive role in cities making. Study on underground streets for the sustainable development strategy is designed to serve the environment for human survival in modern cities.

\section{The Function of Underground Commercial Streets in Modern Cities}

Underground streets in modern cities connect to various buildings or infrastructures. The form of its existence may be an independent entity or attached to some other buildings. The underground streets in modern cities usually show the following aspects of function to improve the living environmental conditions:

(1) Urban traffic function

The construction of underground streets is to solve the problems of ground traffic congestion on roads in cities. In order to ensure pedestrian and general traffic safety, the underground parking lot for commercial facilities is a part of its subsidiary, and the main function is to provide public underground streets underpass, effectively maintain the safety and smooth the flow of traffic at the same time, as is to solve the parking problems in the commercial centers of the cities.

The main starting point for underground streets construction is to control and improve traffic in the area, 
especially for urban road bottlenecks and heavy traffic areas. In order to change this situation of traffic contradiction block, widening the roads or opening up new roads is effective, but a lot of land and the demolition of large buildings will be required, as is a kind of very difficult problems in cities with high density. In addition to building a certain number of viaduct highways, developing the subway and combining underground stations and underground parking lots can improve the original traffic condition. In the area where a large railway station is located, the traffic volume is large and the population density is high. If a considerable portion of the transferring passengers flow goes underground, the mixed running condition of cars on the ground roads will be improved.

(2) commercial supplementary function

Transportation and commerce are two interrelated urban functions. The development of traffic promotes the prosperity of business, and the development of commerce puts forward higher demand for traffic. Business is the most economical part of the underground streets, and the social benefit is very significant. The commercial advantage of the underground streets has its unique performance. On the one hand, underground streets with no raining and no snowing weather factors on shopping, as are very attractive to consumers. The underground streets are of positive significance to the active markets and the economic prosperities of the city. On the other hand, the underground streets provide not only leisure and pleasure but also safe and convenient shopping environment, as for attracting customers.

(3) Comprehensive environmental improvement function

The urban space is a large environment. Air, sunlight, grass, water surface, climate, space, traffic condition, population density, building density, entertainment places and so on, which affect the quality of the urban environmental space. Although the construction of urban underground streets does not involve all the above factors, there is a direct or indirect relationship between them. The construction of underground streets prompt the diversion of people and vehicles on the ground, the reduction of roadside parking, the expansion of open space, the increase of green space and the improvement of microclimate. This will obviously improve the urban environment and further achieve the harmony between man and nature.

In addition to the above functions, underground streets are of certain degrees for disaster prevention function.

\section{The Construction and Development of Urban Underground Streets}

Urban underground streets are the products of the development of modern cities, and have now become architectural types with the symbolic meaning of modern cities. In 1930, the underground passage of Tokyo Ueno station was developed for selling cheap goods, and the prototype is constructed in the underground streets. The real meaning of the underground streets (underground complex) was formed in the years of 1950 to 1960, and the construction of the underground streets reached a climax at that time. Overall, the world's first underground street is the Japanese urban subway station which developed along with underground streets. Underground streets are not only channels, but also squares. At present, China is still in the initial construction of underground streets along with the development of the underground space.

\subsection{Japanese Underground Streets}

Since the birth of the first underground street, after half a century of development, so far, lots of underground streets have been built in Tokyo, Osaka and Kobe. More and more people enter and leave the underground streets every day. Therefore, among all the cities in the world, the underground streets in Japan are most closely related to the daily life of the citizens, and enjoy high international reputation.

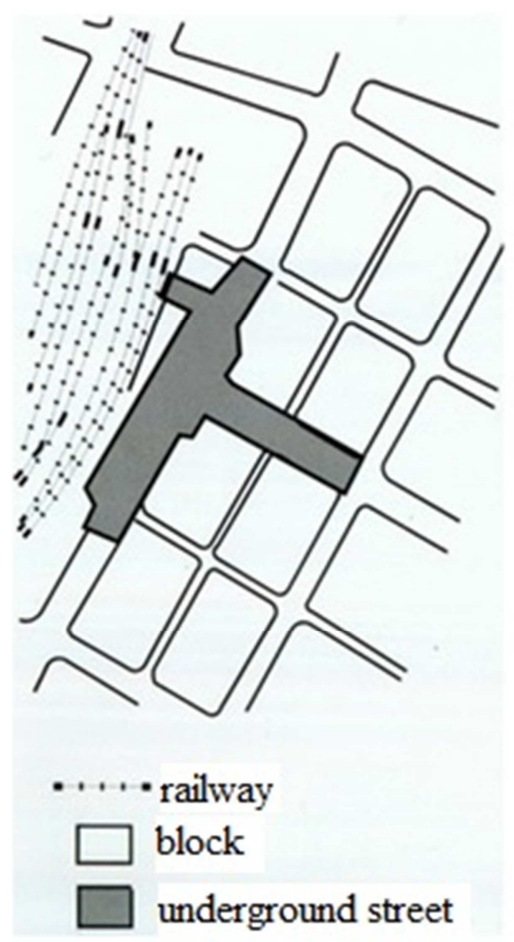

Figure 1. General plan of YAESU underground street.

At the beginning of 1960 , in order to meet the needs of railway passenger volume growth, the new YAESU station, named as the main station, Tokyo station, the famous YAESU Street was planed to be constructed underground. YAESU underground street was built in two phases (1963-1965 years and 1966-1969 years). It is a large underground street in Japan, with a total floor area of more than 70 thousand square meters, plus a connected basement, with a total construction area of 96 thousand square meters. The general plan of YAESU underground street is shown in Figure 1. Subway stations are usually located in the tens of meters and hundreds of meters radius of the center of Tokyo station. They are all connected to the underground part of Tokyo station and YAESU underground street through the underground pedestrian 
passage. One floor plan of YAESU underground street is shown in Figure 2. Although the daily traffic volume of Tokyo station is as high as 80-90 million people, the traffic in the square and main street is orderly, and the walking is separated from the vehicle line. The traffic is smooth, the parking is convenient and the environmental air is fresh. YAESU underground street view is shown in Figure3. It reflects the proper style and features of the modern big cities. The 23 entrances distributed on the sidewalk enable pedestrians to cross the streets and squares into the station through the underground space. The access to the underground parking lots located in the middle of the street allows the vehicles to enter conveniently without affecting the normal driving of other vehicles.

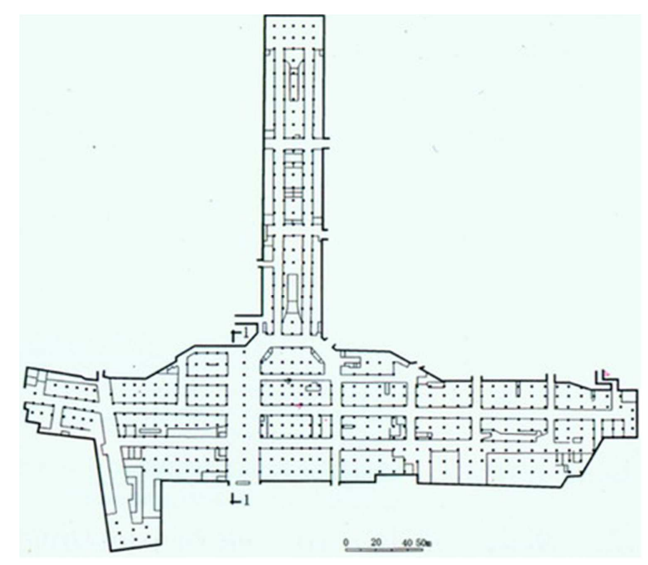

Figure 2. One floor plan of YAESU underground street.

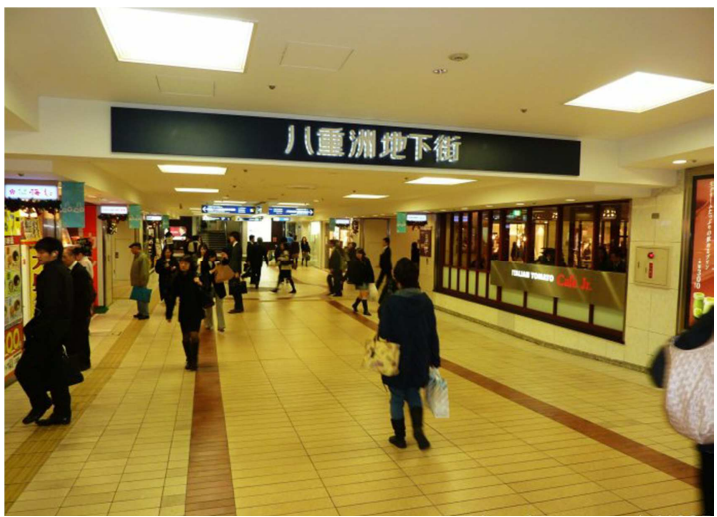

Figure 3. YAESU underground street view.

The underground street in Japan is actually an underground complex, which includes main facilities such as walking passages, shops, parking lots, etc., and is also connected with the surrounding buildings, basement, subway stations or railway stations. Underground streets usually form a network of pedestrians, parking lots, subway stations, and etc. The surrounding large-scale buildings and railway stations form a large concentration point of the city. Underground streets are now distributed in 21 major cities in Japan, with a total area of about 1 million and 100 thousand square meters, about 8 of which are concentrated in the metropolitan area. In the underground streets of Tokyo, the proportion of parking places are close to the public area. The construction of underground walkways and underground parking lots combined with underground streets, as improve the ground traffic under the conditions of increasing and expanding the urban roads. Underground shopping and underground parking provide an environmental space for lots of people. The problem of vehicle congestion is easily solved, as a result, people do not get mixed up on the ground roads.

According to the data released by the Tokyo government in 2014, there are about 63 thousand underground areas that have been developed in Tokyo, of which $40 \%$ are underground roads, subway systems and shopping centers. The size of the largest underground shopping area reached 214 thousand cubic meters, equivalent to 5 large multi-purpose stadium in Tokyo dome was buried. In addition to making full use of scarce urban land resources, distinctive urban network systems with different characteristics have also be built. People can feel the breathing of underground space. The development of underground space in Japan has absorbed the experience of Europe and America, especially the experience of Europe, and innovated in combination with the needs of its own urban development. The development and utilization of the underground space in Tokyo is accompanied by the continuous evolution of the process of urbanization.

\subsection{European Underground Streets}

In the big cities of Germany, France, Britain and some other European countries, during the process of reconstruction and rebuilding of roads and railway systems, combined with the construction of traffic centers, the development of the underground complex is of progressing, and their common features are: large, rich content and complex layout. In Germany, the Nei nigh, Le Louvre Museum in Paris, La Defence, Lei Yale (Les Halles), Sweden, Stockholm and other Nordic cities all have very large underground complexes with characteristics.

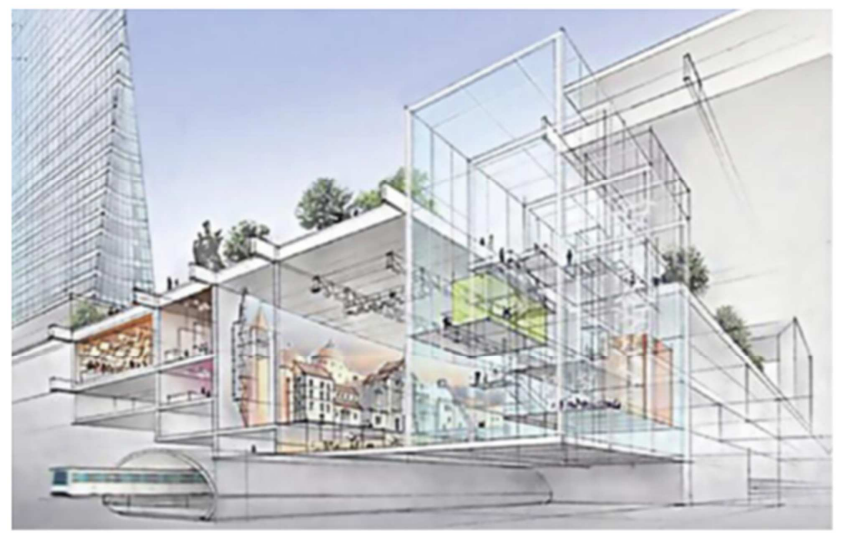

Figure 4. Sketch of La Defense underground space [3].

As one of the central areas in Paris, La Defense is the largest and most important business and commercial center. The location of the area is a modern business area with complete facilities, such as work, residence and amusement. All traffic facilities in La Defense are put at underground space. Sketch 
of La Defense underground space is shown in Figure 4. Among the three floors of underground space, the upper frame platform is of high platform where the road are built for walking. The roads and the building entrances are connected to the ground floor and transit subway station hall. Clear road signs are for guiding the vehicles quickly through. The ground floor is mainly for commercial services, franchised stores and catering and entertainment. The underground two or three floors are mainly underground garage and 26000 parking spaces are provided. Holistic space structure of La Defense is shown in Figure 5.

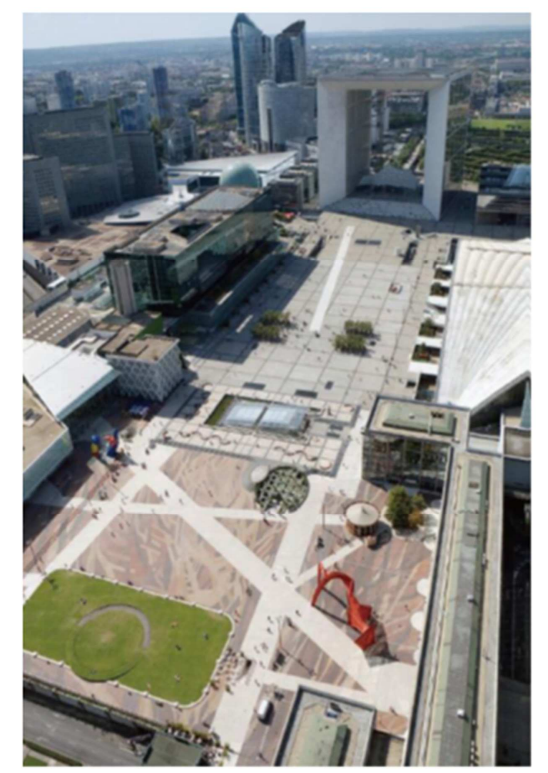

Figure 5. Holistic space structure of La Defense [3]

\subsection{North American Countries Underground Streets}

There are many examples of underground complex in North American cities. American cities with high-rise concentrated buildings, resulting in deterioration of city space environment, therefore, in the most concentrated area of high-rise buildings, such as New York's Manhattan area, the center of Chicago and other places, the building of underground space is very developed for improving environment, and linked with the high-rise building basement into one body, forming a large area of the underground complex.

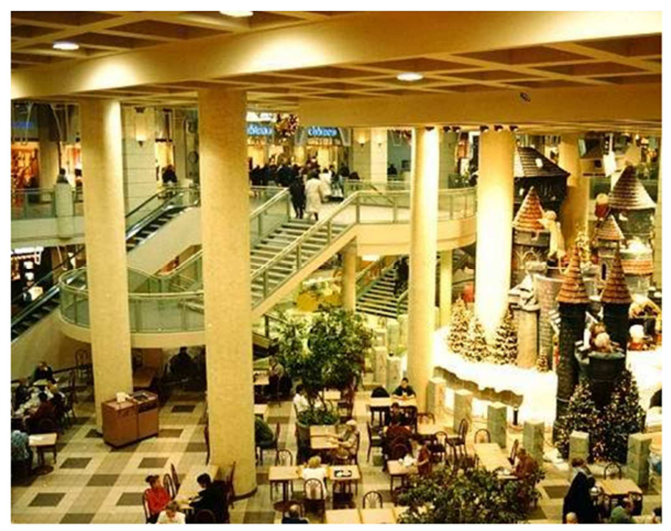

Figure 6. Underground commercial space in Montreal.
The underground complex in Canada has its special meaning, Canada is a cold country in winter, snow has great influence on the ground traffic for half a year long period. The underground complexes, the subways and underground pedestrian streets are very popular. In order to communicate with each other between complexes and important buildings, traffic vehicles and pedestrians are underground, as surely overcome obstacle problems caused bad weather. Montreal has 6 large underground complexes, with a total area of more than 80 million square meters, and still continues to expand. Underground commercial space in Montreal is shown in Figure 6. Through the underground streets, the main high-rise buildings, the public activities and the traffic hub in the center of the city are joined together. Montreal is famous for its 4 to 5 months of winter each year. In February, the temperature will fall to 34 degrees below zero, and the amount of snow can be as much as 2.5 meters a year, and the north cold wind let the human face and eyes uncomfortable. On the other hand, underground streets avoid suffocating heat in the summer. In July, the temperature will rise to 32 degrees. So, the underground space make the commercial and socio cultural activities of the business area be expanded for 12 months of the year. Unlike other big cities in North America, Montreal is a city full of crowds day and night. Most commercial streets are lively, and relatively safe. In fact, 10 subway stations and two subway lines are connected to underground passage and indoor public squares and large commercial centers. Montreal metro space is shown in Figure 7. The underground city is actually another Montreal. In order to avoid the bad weather above, 500 thousand people enter 60 buildings connected to each other everyday, that is, to enter more than 3 million and 600 thousand square meters of space, including $80 \%$ of the total office area and $35 \%$ of the total business area of the urban commercial area.

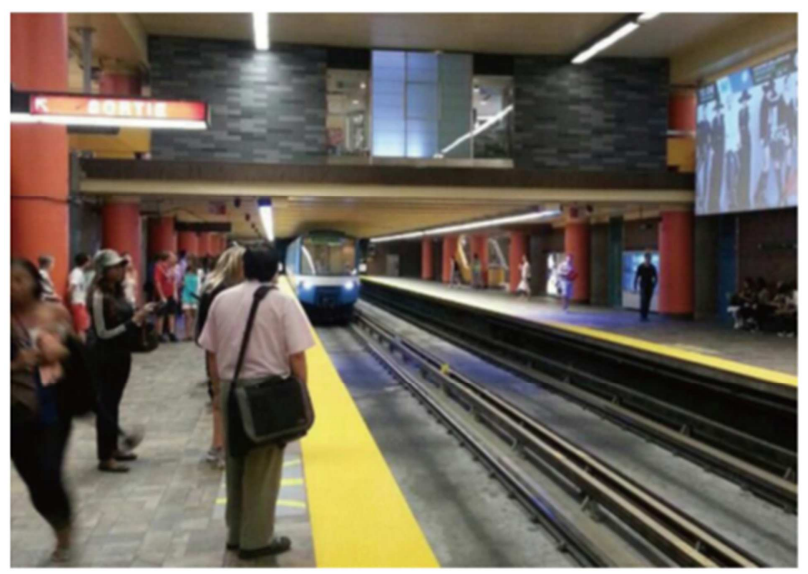

Figure 7. Montreal metro space [3].

For the city of Montreal, the underground streets reduce the traffic conflict between the main cross sections of vehicles and pedestrians, reduce parking demand and reduce air pollution. The distribution of underground space in Montreal is shown in Figure 8. Thanks to the positive cooperative relationship between the underground city and the commercial streets, the core of the business district has kept its vitality. It has also 
become a busy and vibrant area for people and private projects that use business streets and public spaces. The underground city has also become the most important part of Montreal's urban tourism.

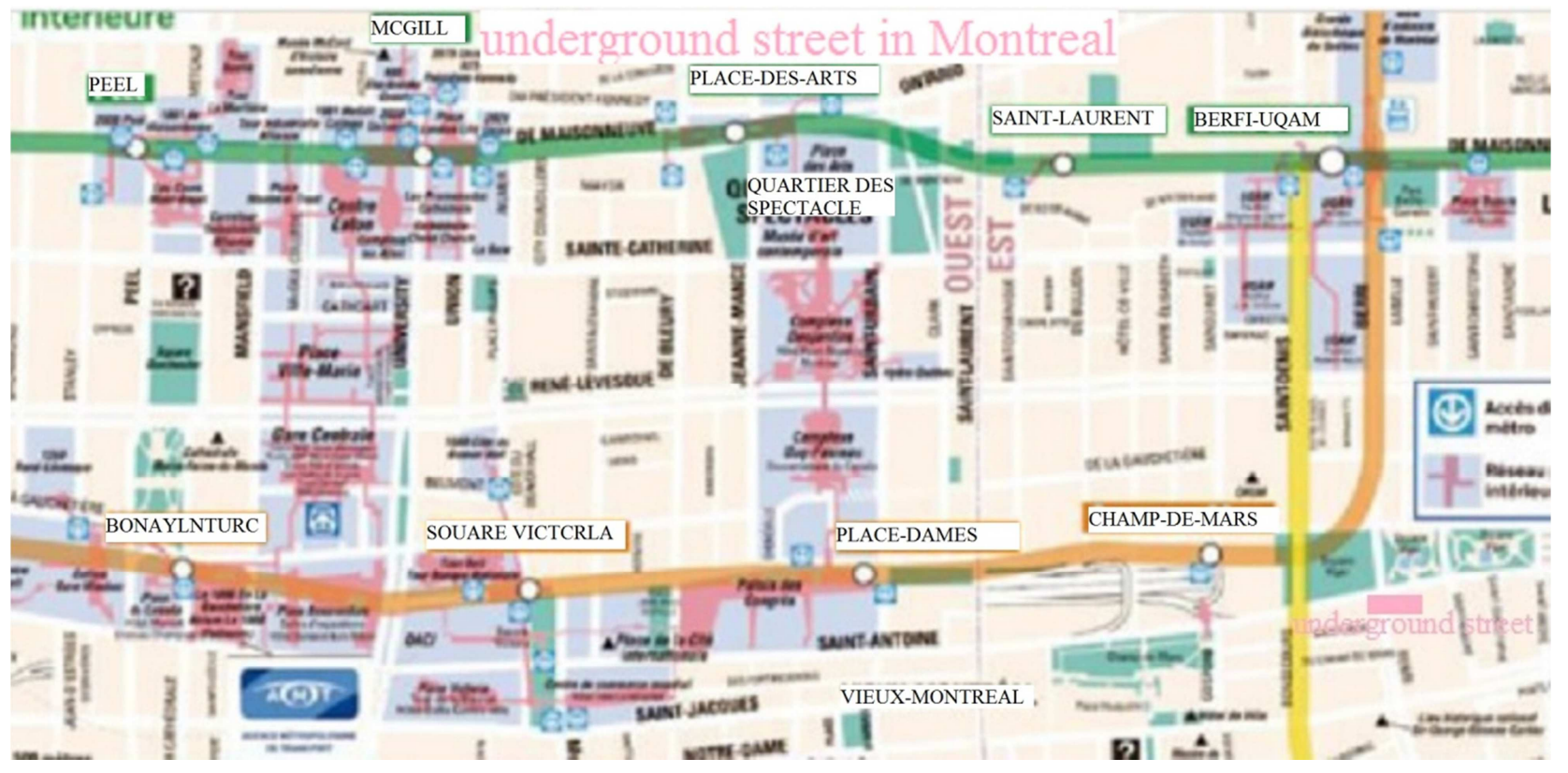

Figure 8. The distribution of underground space in Montreal [3].

\subsection{Underground Streets in China}

The construction of Underground Streets started in China in 1979, and it has become the most common form of urban underground space in China, gradually together with the underground civil air defense projects combined with the urban transformation and development pattern. In recent years, underground streets have been in a rapid developing stage unceasingly not only in quantity but also in scale.

Shanghai City, Shanghai people's Square is not only the most important traditional public activity center but also the most important public transport center. People's Square Underground commercial street in Shanghai is shown in Figure 9.

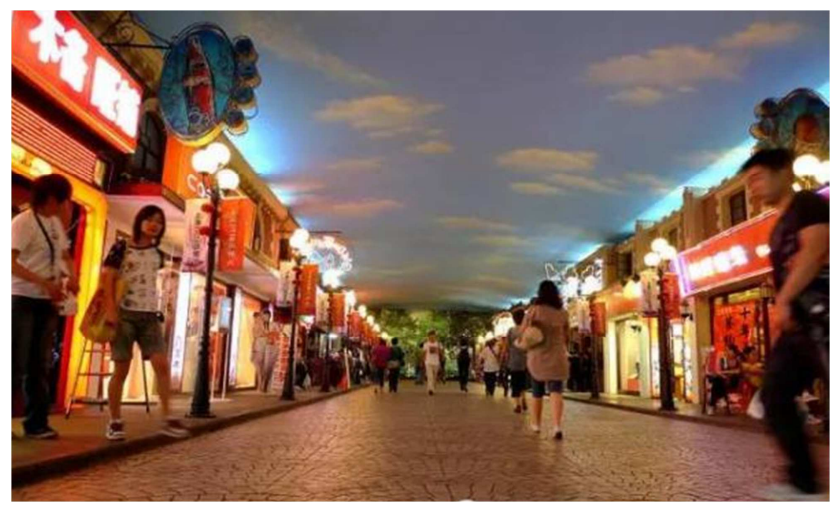

Figure 9. People's Square Underground commercial street in Shanghai.

The investment and construction of the underground street inject new vitality into the people's Square, as is of the live specimens and the historical development of Shanghai city. Shanghai has entered the large-scale development and utilization of underground space. One of the underground
Street entrances of people's Square of Shanghai is shown in Figure 10.

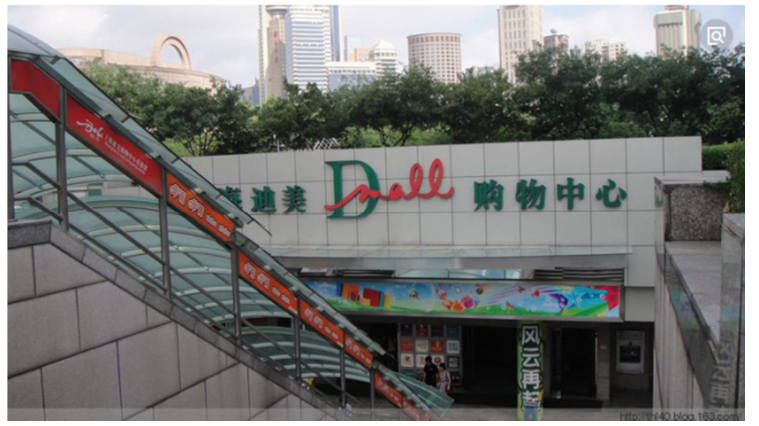

Figure 10. Underground Street entrance of people's Square of Shanghai.

Underground space developments in China are in different scale and level, such as Beijing Zhongguancun, Beijing Financial Street, Shanghai Wujiaochang center, Guangzhou Zhujiang New City, Hangzhou Qianjiang New City Center, etc. as introduce the three-dimensional city in the planning and construction process of the space. Beijing Zhongguancun west district underground car ring corridor is shown in Figure 11. The development of underground space for large-scale integrated has achieved very good results. The construction of underground space in Shanghai city plays the key role of the clear underground space diversification and traffic nodes of underground space integrations. The construction of underground space effectively guide and promote the space in key areas, to meet the requirements of the ascent of the whole urban function. The total underground space is expected, by the end of 2020 in Shanghai City, will reach 100 million square meters. The overall framework of regional development of underground space is the center of the city to 
the people's Square as the core radiating to the adjacent areas. By linking underground transportation facilities and other infrastructure in the city and Metro regional center, the underground streets are clearly important parts of the city. From the point of view of the implementation, the overall pattern is basically formed, and the urban underground street network effect depends on the urban rail transit system.

In the past 10 years, the annual average developed area of underground space in Beijing is more than 3 million square meters. Beijing Zhongguancun west district underground pipe corridor is shown in Figure 12. The potential underground space within the depth of 10 meters in downtown of Beijing is up to 90 million square meters, and the potential underground space within 30 meters depth is up to 209 million 100 thousand square meters. According to the area of the 7140 square meters of a standard football area, the underground space within the depth of the 10 meters of the center city can also build 12605 football fields, and the available space within 30 meters depth underground is equivalent to 29285 standard football fields. It has been suggested that Beijing can build the spatial structure of the landmark underground buildings. In Beijing underground space, buildings to be constructed on the basis of the 8 directions will create 8 iconic underground complexes forming the future underground streets which includs the Zhongguancun area, Olympic Park area, CBD area, Wangfujing area, Shougang area, Lize area, Fatou, Nanyuan area and deputy center of Beijing in Tongzhou area.

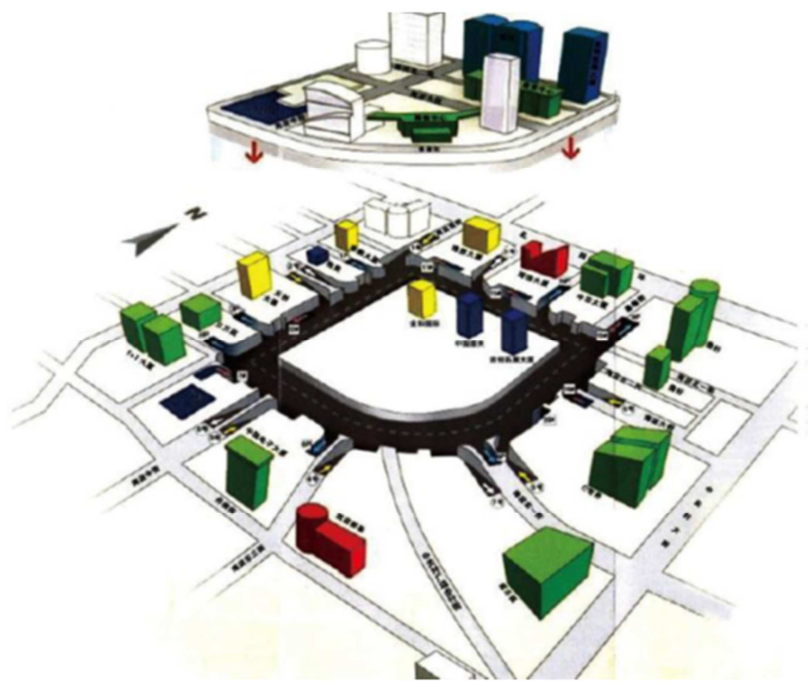

Figure 11. Beijing Zhongguancun west district underground car ring corridor [3].

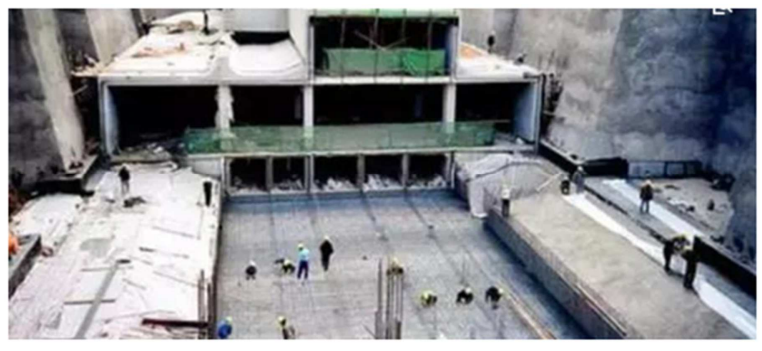

Figure 12. Beijing Zhongguancun west district underground pipe corridor.
However, the development of urban underground space in China is not very satisfactory. The development of cities in China lays stressing on the planning and construction of urban land, but less considering the construction of underground drainage and other supporting facilities. One of the reasons for shortage of urban water drainage system caused by torrential rain in summer of 2012 in Beijing is that urban underground space is continuously occupied and difficult to meet the upgrading of water supply and drainage system. There are few effective guidelines for the urban underground planning, poor implementation of the planning, and less connection between the underground space and the special planning of traffic and municipal affairs. On the other hand, because of the particularity of the underground space and the irreversibility of its development, the design of underground space needs to be demonstrated in detail in the early stage of the planning, and the planning plan with strong implementation and clear planning objectives are needed. In this regard, it is a deficiency for our existing urban planning system.

\section{Suggestion for the Planning and Construction of Underground Space}

Underground streets which effectively promote the rational development of urbanization are the main forms of urban underground space utilization, also they are huge resources of human activity space expansion. The development of the underground streets shows both the valuable space and the active circumstance. The construction of underground streets improves the transportation of the city, ensure that all kinds of material stored underground getting enough space in the modern cities. In order to meet the operation and social progress of modern cities and meet the needs of residents' work and life and entertainment and leisure, underground streets play an important role. According to the national conditions of China, the planning and construction of urban underground streets urgently need to be studied and the following problems should be solved.

(1) Strengthening the systematic and dynamic programming for underground space development

The development of urban underground streets is an inevitable way to expand the urban land resources. We should develop the underground space scientifically and rationally for expanding the urban space resources to the underground, as forming the new direction of the expansion of urban space resources. The development of underground streets is irreversible. Once developed, the cost of later adjustment will be large. Therefore, it is particularly important to identify reasonable and scientific underground space development functions. The development function of underground space should be coordinated with the whole function of the region, overall planning and linkage.

(2) Scientific demonstration of the scale of underground street development

The demand forecast of underground streets is an important link in the development and planning of urban underground 
streets, and it is also an important basic study of the urban planning system. Considering the high cost and high difficulty of the underground streets development, it is an important way to realize the sustainable urban development by determining the scientific and reasonable development scale of the underground streets. At present, the planning of underground streets is mainly concerned with the provisions of the layout form. Although some development capacity is involved, the scale demonstration has not been further strengthened enough. On the whole, we should make reasonable suggestions for the scale of the development of each block in cities.

(3)Strengthening the development of underground streets around the subway station

Rail transit construction is an important opportunity and key node of underground space development, so making full use of the development of metro station will drive underground streets development. The vigorously strengthened land surrounding of subway stations will achieve a result of comprehensive implementation of underground integrated system and network system, as has important significance to the sustainable urban development. For rail transport site focused on the study, according to the function and layout, the preparation of the rail transit station and surrounding underground streets planning guidelines should enrich the function of underground space development of the surrounding areas for guiding and controlling the size and connectivity of constructability requirements. By means of planning control elements and controlling content, it is important to make full use of the leading role of rail transit stations, as is for promoting the development of the surrounding areas of the site in high efficiency.

(4) Strengthening information management of underground streets planning

At present, the content of the planning and construction of the underground streets has not been included in the unified planning information data management platform. Under the background of urban planning information, underground streets planning should also be drawn on the experience of planning information management on the ground and be carried out for information management. Government should sort out the information channels of various departments, realize the importance of underground space status data. Planning and compiling data and building informational base, as will promote the cooperation and resource sharing of departments, and promote the efficiency of underground street development and utilization.

(5) Strengthening application of BIM technology in urban underground space

Applied to the planning: Based on the BIM platform, combining the development direction and development ideas of the city as a whole, the urban underground space planning is integrated into the urban overall planning. Through the combination of BIM and GIS platform, the BIM model established can not only express the planning thought of the planners in three dimensions realistically, but also display the internal information of the buildings in details.
Applied to the designing: Underground space development and utilization and cooperation need multiple disciplines, and by means of collaborative BIM technology, the architecture and structure and water system and HVAC (Heating, Ventilating and Air Conditioning) equipment and electrical machinery and other professional work can be footed on the basis of the same model, as can avoid the "information gap", so as to make the design information timely update and transfer, and help to improve the quality and efficiency of design.

Applied to construction: By using BIM technology, multiple construction plans and comparative analysis are easily simulated, so as to find out design errors and eliminate construction risks and choose the best construction plan. BIM technology is applied to simulate and coordinate the construction of various specialties, determine the best construction process, the best mechanical route and the range of personnel activities, so as to avoid the phenomenon of professional construction confusion.

Applied to the maintenance management: By BIM technology integration, various stages of the project life cycle information in the complete information database is formed after the completion of the project, as can facilitate the work of the daily maintenance and management. BIM model can be used to check the equipment, so as to carry on the early warning of the service life of the expiring equipment for timely replacement or maintenance.

\section{Conclusion}

\subsection{Three-Dimensional Planning}

The development and utilization of urban underground space is not only a comprehensive interdisciplinary subject, but also a huge new industry which involves a wide range. It is a long-term development task. Only the planning of the underground space can lay the foundation for the exploitation and utilization of the underground space. The key to the planning of underground space is to deal with the relationship between the integration of the underground facilities and the underground space. Sketch of urban sinking square is shown in Figure 13. We should treat the urban and the underground space as a whole and set up the urban planning system in line with the requirements of the three-dimensional construction of the city.

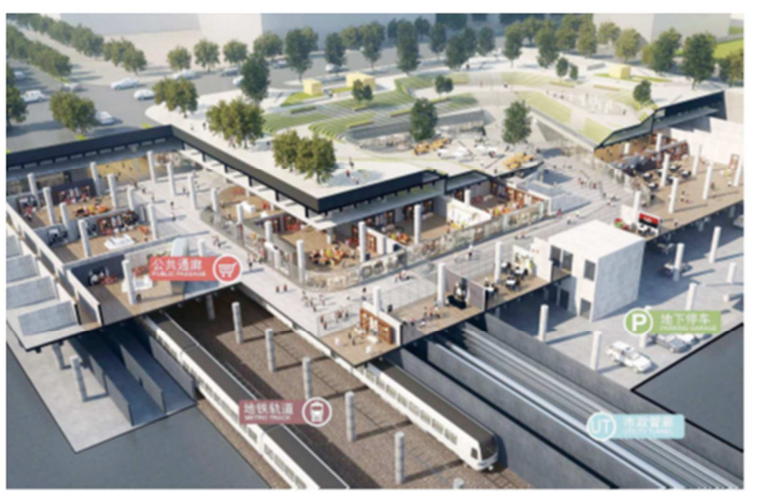

Figure 13. Sketch of urban sinking square [10]. 
With the increasing speed of today's global urban development pace of the underground space development, the utilization of resources has become one of the important contents of the modern city planning and construction, and will increasingly become the inevitable trend of the urban three-dimensional and modernization, and will also be one of the most effective way to solve the modern city problems.

\subsection{Improving Urban Environmental Space}

The form of underground streets has played a positive role in improving the cultural ecology and walking environment, and in promoting the development of urban public space, and in improving the urban traffic function, and in complying the business functions of modern cities, as has gradually become popular for people.

\subsection{Realizing the Importance of Underground Streets}

Modern cities are increasingly entering the era of urbanization. The cities all over the world are developing and expanding rapidly. The development and utilization of underground space is more and more important in the construction of modern cities.

\subsection{Solving Urban Traffic Congestion}

From the view point of traffic, the city is the place for living and communication, and it is not only the people's material and spiritual life but also social focus. With the development of economic growth and the growth of population, the construction of underground streets is one of the effective ways to solve the urban traffic congestion.

\subsection{Realizing the Comprehensive Roles of Underground Streets}

Taking into account a variety of underground streets beneficial functions, and combined with the urban traffic congestion situation, the planning and construction of underground streets will not only improve the comprehensive environment of city, but also achieve great economic benefits, as will be aimed for far-reaching social significance and important practical significance.

\section{References}

[1] WANG Yuning, Spatial Integration of Urban Complex and Urban Rail Transit, College of Urban and Environmental Science, Tianjin Normal University, 2017. 03.

[2] XIE Heping, GAO Mingzhong, ZHANG Ru, XU Heng, WANG Yongwei, DENG Jianhui, The subversive idea and its key technical prospect on underground ecological city and ecosystem, Chinese Journal of Rock Mechanics and Engineering, Vol. 36 No. 6, June, 2017.

[3] Qi Kang, development and utilization of city underground spaces, 2017. 01.

[4] Liu Jieyi, Discussion on Rising and Development Experience of Japanese Underground Town, International city planning, 2007 Vol. 22, No. 6.

[5] Peng Fangle 1, 2, Qiao Yongkang 1, 2, Chang Jianfu 3, Zhang Dichuan 3, Study on the Regulation System for Underground Streets in China, Chinese Journal of Underground Space and Engineering, Vol. 13, Aug. 2017.

[6] Liu Jieyi 1, Shu Yu 2, Study on Use of Underground Space in Raising Urban Regional Competitiveness_taking Design of Jian-Jun Road Underground Street in Yancheng for Example, Chinese Journal of Underground Space and Engineering, Vol. 10, May, 2014.

[7] Study on Development, planning and Construction of Urban Underground Streets, Journal of Tianjin Institute of Urban Construction, Vol1. 14, No. 1, Mar. 2008.

[8] Tong Lin $\mathrm{Xu}$. The planning and design of the underground commercial streets. Beijing: China Construction Industry Press, 1998.

[9] Nie Bihua. Development of China's underground streets. Underground space, 1989, 9 (2): 24 27.

[10] Huan Zhengxue, Liu Baokui, Liu Guangcheng, Suggestion for Underground space Development, 2016. 10. 